\title{
The Rwandan Crisis: \\ A Watershed for Humanitarian Intervention
}

\author{
BRENDAN M. HOWE*
}

Tin years on, the impact of the inaction of the intornational community during the Rwandan crisis is still being felt. This article considers normative, legal, and realpolitik constraints operating upon decision-makers, contending that the first wo should have enabled derision-makers to authorize intervencion if not actually requiring them so to do, and that the international community's non-intervention in genocide was, therefore, due to considcrations of national intercst. However, international law played a significant role in framing excuscs for inaction, and the end of the crisis saw intomational docision-makers having their hands forced by pressure from their internal and external communiries, promising that non-state-centric humanitarian considerations could play a greater role in future conflicts such as Kosovo and Sudan. Thus this article demonstrates not only that liberal claims of a new world order at the end of the Cold War were premature, but also that post-Rwanda power-political considerations no longer fully explain normative war-fighting decision-making.

Keywords: Rwanda, Genocide, (humanitarian) intervention, legality (international law), norms, decision-making

\footnotetext{
* Direcr all correspondence to Brendan M. Howe, Assiscant Professor, Graduatc School of International Srudies, Ewha Womans University, 11-1 Daehyun-dong, Seodaemun-gu, Seoul, 120-i50, Korea; Tel: 82-2-3277-3348; E-mail: bmghowe $\sqrt{2}$ hotmail.com
} 


\section{INTRODUCTION}

F

rancis Fukuyama declaring the 'end of history' in 1989, and the former US President George Bush, in a State of the Union Address in January of 1991, declaring a "New World Order '.' to achieve the universal aspirations of mankind - peace and security, freedom and the rule of law,'(Ross 2002, 247) caused a great stir and helped revitalize debate in security studies, but they were essentially referting to liberal tenets that were decades, or even centuries old. The basic liberal argument is that at some point the world has radically changed, forcing a re-evaluation of the nature of international interaction. In the brave new world, the logic of cooperation takes over from the logic of competition and survival of the fittest. The promotion of shared values and interests supercedes the pursuit of selfish national interest, morality is placed at the centre stage of statecraft, and the basic human concern for the wellbeing of others makes progress possible.

Liberal beliefs do not make war unthinkable, but do challenge traditional assumptions of when it is justifiable to wage war. Ihere is no more dramatic manifestation of liberal kadership than so-called 'normative war-fighting' or militarized humanitarian intervention. While the end of the Cold War may have marked the end of ideological stalemate in the UN Security Council and the 1991 Gulf Wat an increased concern with fighting legal wars, the Rwandan crisis was an horrific demonstration of how far removed was the international community from the liberal vision at this time, and of the continued dominance of national interest as the guiding principle for when nations go to war.

Yet the aftermath, guilt and public recriminations following the failure of the international community to intervene in Rwanda have demonstrably provided incentives for future interventions. Rwanda may have demonstrated that claims of a new liberal world order were at hest premature, but the impact of Rwanda guarantecd that cynical considerations of national interest would no longer be the sole consideration of when liberal states would go to war, and thus to a certain extent signaled the demise of the old realist or power-political world order.

Ten years after the crisis, this article contrasts the normative and legal demands that should have empowered international decision-makers to take action with the constraints of narrow national interest in order to offer a critique of the supposed post-Cold War liberal world order. However, it also addresses the impact of the crisis upun future cases and the degree to which it marks a turning-point in normative war-fighting. It therefore, uniquely, debunks both the dominant paradigms of international relations theory by tracing the impact of the practical realities faced by decision-makers.

\section{HISTORY}

Rwanda's early history saw the seeds of genocide sown by the policies of nembers 
of the international community (German and Belgian administrations, French paternalism, the League of Nations and the UJN). Thus the argument that the genocide was an African problem best left to Africans was as specious as it was callous. Intemational decision-makers were therefore obligated to act not only by the demands of a shared humanity, but also through responsibility for their predecessors' actions.

On 6 April 1994, the plane carrying the presidents of Rwanda and Burundi back from a meeting in Tanzania was shor down by a rocket, killing all on board. Blame was quickly foxused upon Rwandan Tutsis by Hutu Power extremists. The assassinations launched several weeks of intense and systematic waves of massacres in which as many as 1 million people are estimaced to have perished and led to the resumprion of the civil war, "provoking a mass exodus of people away from the fighting with some 2 million Rwandans - more than 25 per cent of the population - quickly beroming displaced within Rwanda or beyond its borders.' (IN 1996,3 ).

No normative clains tegarding the moral value of the state could weigh as anything more than insignificant compared with the cvils being perpetrated by the regime. Thus it seems clear that decision-makers in the dominant states of the international community must, at least at the time, have acted in accordance with the dictates of a different set of enabling and constraining criteria.

We turn now to consideration of the dictates of international normative criteria. This will be followed by analysis of international legal considerations, and finally the national interests of some of the major players on the international stage. We will sec that normative rules demanded action, legal rules werc at lcast permissive, and only national interests weighed against action being taken. Thus not only was a liberal utopia not in being at this time, but even the more limited "rule of law" new world order proclaimed by President Bush was threatened, as liberal states continued to act with self-centred cynicism.

\section{NORMATIVE JUSTIFICATIONS FOR INTERVENTION}

Normative constraints upon international decision-makers in such cases may be divided into the jus ad bellum (the justifiability of going to war) and the jus in bello (the justifiability of actions raken) The jus ad bellum is further divided into a number of criteria generally accepted by scholars and practitioners of international relations.

The firse criterion is that a military operation must only take place with just cause. The existence of acts of genocide is universally considered as fulfilling this criterion providing other just war criteria are met. The second criterion is that of right intention. Any intervention aimed at stopping the killing would have fulfilled this criterion. It would also have been no problem for actors to receive the endorsement of competent authoritics (the third critcrion), as both the UN and Organisation of African Unity directorates were pushing for action by states with the capacity to intervene.

Given that most of the killings were carried out by very primitive weaponry a 
determined international effort would have had a very high probability of success, thereby fulfilling the fourth just war criterion. General Dallaire, the commander of UN forces, claimed that: "I could have stopped them. We could have stopped the militia at that time with force. All I needed were the troops I had on the ground plus anorher 2,500 men' (Neuffer 2002, 117). Three years later, the Camegie Commission on Preventing Deadly Conflict, the Institute for the Study of Diplomacy at Georgetown University, and the US Arny concurred that Dallaire's assessment was an accurate one and that a force of 5,000 operating with air support, logistics, and communications, and deployed with a Chapter VII mandate, 'could have averted the slaughter of a half-million people" (Whecter 2000, 225).

In terms of proportionality of ends (the fifth criterion), it is doubtful whether any would claim that the end achieved by non-intervention was preferable to that which could have been brought about by a determined and timely intervention to stop the genocide. Even normative considerations of 'last resort' are overcome as far more suffering was entailed as a result of the delay than would have occurred as a result of a speedy, even hasty intervention.

The jzu in bello also consists of a number of criteria, the first being the proportionality of means. No commentator would consider the use of 5,000 UN peacekecpers to stop genocide and save the lives of hundreds of thousands a disproportionate use of force. Even if the UN troops were given a strong mandate to open fire on the perpetrators of genocide, it is unlikely that they would have killed as matry Hutu as died in the refugee camps after fleeing the advancing RPF forces, let alone the number of human lives that were lost as a resule of not acting.

The principle of discrimination, which imposes an obligation upon intervening forces to discriminate between combatants and non-combatants, poses a more complex problem. In Rwanda, 'non-combatants' were often carrying out the genocidal killings. As noted in the UN Blue Book report, 'political party militiamen and gangs of armed civilians went from house to housc killing thousands of 'Iutsi civilians' (UN 1996, 37). However, the normative principle behind the doctrine of discrimination is the protection of human life. Although the genocide in Rwanda was one of the greatest instances of human suffering since the Second World War 'the capacity of the Inited Nations to reduce human suffering in Rwanda was severely constrained by the unwillingness of Member States to respond to the changed circumstances in Rwanda by strengthening UNAMIR's mandate and contriburing additional troops.' (UN 1996, 4).

No amount of mitigation based on the difficulty of identifying combatants, killers, the victims and who constituted legitimate targets for military action can excuse the deliberate hamstringing of the $\mathrm{LN}$ effort. International leaders and UN staff treated the genocide as an unfortunare consequence of the war, something akin to "collateral damage' and devoted their encrgies to trying to obtain a ceasc-fire between the belligerents. "They waited two weeks to take action and then it was to reduce the number of peacekecpers in Rwanda.' (Des Forges 1999, 595). 
The international community failed to fulfil its obligations under the principle of discrimination because they did not take sufficient measures to ensure that minimal suffering was caused to civilians during the time of war. This duty is incumbent not only upon the belligerents but also upon extemal agencies that have the capability to protect civilian lives while a conflict rages.

As a result, in a report to the Security Council on 31 May, Boutros-Ghali noted that:

The delay in reaction by the international community to the genocide in Rwanda has demonstrated graphically its extreme inadequacy to respond urgently with prompt and decisive action to humanitarian crises entwined with armed conflict. Having quickly reduced UNAMaR to a minimal presence on the ground, since its original mandate did not allow it to take action when the carnage started, the international community appears paralysed in reacting almost two months later even to the tevised mandate established by the Security Council. We all must recognize that, in this respect, we have failed in our response to the agony of Rwanda, and thus have acquicsced in the continued loss of human lives. Our readiness and capacity for action has been demonstrated to be inadequate at best, and deplorable at worst, owing to the absence of the collective political will. (UN 1996, 51)

Once the crisis had reached this stage, the final criterion of jus in bello, the concept of a limited war, could in all probability never have been brought into play. A return to the status quo ante bellum was neither possible nor desirable, and while a limited intervention at the start of the massacres could well have been successful, after the death of so many there was no solution available save that of significant regime change, violation of sovereignty and punishment of the guilty. It is understandable that calls for the ultimately victorious RPF to return to the negutiating table with the perpetrators of genocide have met with a less than warm reception.

Member States did not respond guickly to the Secretary-Gencral's request in May 1994 for contributions of troops, equipment and airlift services to meet the requirements of LNAMIR II, and those Member States that did offer to provide troops did not possess certain essential equipment. It scemed that not only wete Pcrmanent Mcmbers unwilling to provide troops, they were also extremely hesirant to give, or even lend equipment that would allow others to intervene. Thus decision-makers (with a few honourable exceptions such as the representatives of New Zealand and Czechoslovakia) acted in accordance with a set of enabling and constraining criteria different from those of normative justification for intervention. International decision-makers knew what was happening, but either decided that they were not bound to act, or that the events did not amount to genocide, and only such a universal 'bad' compelled chem to do so. We will first turn to whether, with knowledge of at least some 
of the cvents transpiring in Rwanda, they were cither enabled or bound under intemational law to act.

\section{LEGAL JUSTIFICATIONS FOR INTERVENTION}

Rwanda was clearly a failed state by the time the genocide was taking place, and as such open to legal intervention. Sovereign rights accruc with the achievement of de fato and de jure control over a territory. At no time during the crisis did any parry possess either, let alone both of these prerequisites. The interim government acted on the international stage as if it was the rocognized government on Rwanda, but anly a government of nacional unity created in accordance with the Arusha Agreement could have claimed this legitimately. Moreover, as time progressed the interim government controlled a rapidly shrinking portion of Rwandan territory, thus losing its de fatto legitimacy. Although the rebel forces increasingly gained de facto legitimacy, it was not until the crisis was over that the international community endowed the new government with de jure recognition.

Under Arcicle 39 of the UN Charter the Security Council could have determined the situation in Rwanda a 'threat to the peace, breach of the peace, or act of aggression,' and, given the cross-border fighting, refugee flows and mass killings, there was sufficient evidence for at least two of these conditions. Articles 43 and 44 would then have allowed a military force to be assembled of concingents from Member states, and then this force could have been inserted in accordance with Article 48. The fact that the far less legitimate French intervention rapidly received a Chapter VII mandate through a unanimous vote of the Sccurity Council shows the feasibility of this approach. Yet although Resolution 918 (17 May), authorized an expanded force and mandate for UNAMIR Il, the international community appeared reluctant to deploy the strengthcned peace-keeping operation.

On 8 June the Security Council passed Resolution 925 calling for the immediate deployment of two additional battalions and an extension of the LNAMIR mandate to 9 December 1994. Yet still nothing happened, and at the annual Summit of Hcads of Srate of the OAU, held in Tunis on 13 June 1994, Boutros-Ghali lambasted the "bitter failure" of the "international community as a whole.' Despairingly, with the deployment of UNAMIR II effectively stalled and a time frame of three months opening up for the undertaking of duties under the new mandate, on 19 June the Secretary-General mooted the possibility of Ftench intervention. The Security Council swiftly concurred; on 22 June adopting Resolution 929 whereby acting under Chapter VII it authorized member states cooperating with the Sectetary-General to establish a temporary operation under French command and control.

Thus the simation in Rwanda was sufficiently horrific for members of the international community, acting cither individually or collectively, to gain legal endorsement for intervention; and international law, as a whole, is essentially permissive of acts of 
intervention under such conditions. That members of the international community did not act to prevent the genocide until it was too late demonstrated they did not feel compelled by international legal instruments to do so.

In fact, much of international law is permissive rather than prescriptive, enabling states to intervene militarily within the borders of another state, but not requiring them so to do. However, the crime of genocide constitutes an important exception to this rule. In ignoring the normative and leyal obligations imposed upon the intemational community when faced with genucide, decision-makers were either dismissing the notion that genocide was occurring, or dismissing the idea that they worc indeed structurally bound to act when confronted with it. Although decision-rnakens attempted to claim the first exemption - that genocide was not in fact taking place - this was done precisely because of an awareness of obligation and subsequent compunction under the second clause.

By far the majority of 'the teachings of the most highly qualified publicists of the various nations,' (recognised as subsidiary means for the determination of rules of law by the Statute of the ICJ), hold the position that it is not only a right, but also a duty of all states to take action against the perpetrators of genocide. Thus for Destcxhe, the Convention on the Prevention and Purishment of the Crime of Genocide is "a legal instrument that has been ratified by 120 countries and which, according to the International Cuurt of Justice, holds to generally accepted values which oblige all states'. to "punish and prevent genocide"" (1995, 14-15). Wheeler concurs $(2000,209)$, as does Des Forges (1999, 595).

Indeed, it is hard, upon reading the Convention, to come to any other conclusion. Under Article I the Contracting Parties undertake to prevent not just to punish the crime of genocide. Furthermore, "any Contracting Party may call upon the competent organs of the United Nations to take such action under the Charter of the United Nations as they consider appropriate for the prevention and suppression of acts of genocide.' None made such a call, but had they done so there would have been an additional obligation for multilateral intervention. The only legal defence for inaction would have heen doubt concerning whether genocide was actually taking place.

According to Article II of the Convention on the Prevention and Punishment of Genocide the crime and its related obligations takes place when any of the following acts are committed with intent to destroy, in wholc or in part, a national, cthnical, racial or religious group, as such:

Killing members of the group:

Causing serious bodily or mental barm to members of the group:

Doliberately inflicting upon the sroup conditions of life calculated to

bring abaut its pbysicul destruction in whole or in part;

Imposing measures intended to prevent birtbs within the group;

Forcibly transferring children of the grout to another group.

Both the Secretary Gencral of the UN and the Special Rapporteur noted the extent 
of the massacres as unparalleled (INN 1996, 569-92). Although intent is difficult to prove, for the Special Rapporteur it was clearly contained in the media's constant incitements to murder, and even if that were not so, it "could have been deduced from the facts themselves, on the basis of a variety of concordant indications: preparations for the massacres $\cdots$, number of Tutsis killed and the result of a policy of destruction of the Tutsi' (UN 1996, 571).

Thus even if members of the international community were somehow ignorant of the explicit statements of intent by members of the interim govcrnment, failed to take into account the warnings of NGOs, and didn't receive UN reports, they should still have been able to picce together what was happenitig from other information, and see that all the conditions for labelling what was happening a genocide had been met. Yet the Permanent Members of the Security Council, and their leading decision-makers, on the whole steadfastly avoided the ' $\mathrm{g}$-word' and its implications.

However, although the international legal regime did not appear sufficient to compel decision-makers to act, it did appear sufficient to structure their evasions. The reluctance to term the Rwandan crisis a genucide stems directly from the fact that decision-makers felt that such an admission would obligate them to act. When tackled on the Clinton administration's reluctance to use the 'g-word', substituting instead the phrase 'acts of genocide may have occurred,' Christine Shelley, a State Department spokeswoman, admitted that the scmantic squirm was due to the "obligations which arise in connextion with the usc of the term" (Gourevitch 2000, 152-3).

Thus for those compiling the Report of the Independent Enquiry, "the lack of will to act in response to the crisis in Rwanda becomes all the more deplorable in the light of the reluctance by key members of the International Community to acknowledge that the mass murder being pursued in front of global media was a genoxide.' Furthcrmote, the Convention 'explicitly opens the opportunity of bringing a situation to the Security Council. Arguably, in this context, the members of the Security Council have a particular responsibility, morally if not explicitly under the Convention, to reacr against a situation of genuride' 'The reluctance by some States to use the term genocide was motivated by a lack of will to act, which is deplorable.' (1999).

The final question remains, of coursc, why did decision-makers feel the need to try to avoid being compelled to act in accordance with incernational law? Why were they motivated by a lack of will to act? Sadly, the answer rcturns us once more to the chauvinistic self-interest of states.

\section{NATIONAL INTERESTS}

Boutros-Ghali identifies a general 'peacc-keeping fatigue' as a cause of the unwillingness of members to contribute troops and funding to UN operations (UN 1996, 
50). UN operations were seen as financially ovethlown, wasteful, incompetently managed, and irrational in terms of cost-benefit analysis, as contributing states were open to just as much criticism for missions going wrong as they were for failing to act, but with significant additional costs. 'I'his precipitated a vicious circle of states not willing to contribute men and material resources to under-funded $\mathrm{UN}_{\mathrm{N}}$ missions which would place them at significant risk, and this in turn leading to further chronic under-funding.

At least initially, individual national interest in terms of financial well-being and security of one's own citizens, and national prestige and influence were to the fore in Rwanda. The major state entities involved in the crisis were Belgium (the former colonial power), the US (as world leader and major contributor of both money and manpower for UN operations since the end of the Cold War) and France (Security Council Permanent Member, leader of La Francophonie, and eventual intervening power). Thus in this section we will consider the state-centric, realpolitit rationale of decision-makers from each of these countries.

Belgium's policy towards Rwanda was confused from the outset. On the one hand, as former colonial masters, Belgians felt a degree of responsibility for the country. On the other, Belgian decision-makers werc kcenly aware of their limited resources. Belgium was initially active in support of a multilatcral intervening task force under a UN umbrella. Indeed, Willy Clacs, the Belgian Foreign Minister, had asked the United Nations to modify the UNAMIR mandate to allow the international soldiets to intervene militarily and stop the slaughtes (Prunier 1995, 234). Yet Belgian nationals were being deliberately targeted by Hutu Power extremists in terms of propaganda, incitement to murder and physical acts. The brutal torture and execution of the Belgian peacekeepers hit the country hard, seeming to cause a paralysis among both the people as a whole and decision-makers. Thus in the long run Belgium hardly reacted at all.

$\Lambda$ s the world's leading economy and military power, America faced greater calls upon its resources from the international community than did any other state, and therefore was particularly suxceptible to the 'pracekscping fatigue' mentioned above. After the Arusha Accords were signed, Rwanda was no longer seen as a priority, and in the light of rising costs and thinly spread resources, the US was balking at paying 30\% of the peacekeeping costs (Neuffer 2002, 101). More importancly, America was most seriously affected by the Somalia debacle, as it had been American troops who were killed and then had their bodies dragged through the streets of Mogadishu. Somalia drew comparisons with Vietnam, and created a similar anti-interventionist mind-sct among American decision-makers and the wider American public.

In response the Joint Chiefs of Staff had pushed for a limit on US involvement in any UN mission, and Members of Congress had expressed concerns that the US was acting as the world's policeman. The result was Presidential Decision Dircctive (PDD) 25, which was made public at the beginning of May. This stated that the US would contribute to opcrations 'only where its nation's interests were engaged 
and that its soldiers would always remain under national command and control' (Wheeler 2000, 224). America had no strategic interest in Rwanda. Africa had receded in importance since the end of the Cold War, and Rwanda had never featured prominently in American policy in the first place (Klinghoffer 1998, 97). Thus on 25 May Clinton came out against intervening in Rwanda precisely because there was no national interest at stake.

Not only did the Americans fail to intervene, they also took the kead in restraining the international community as a whole from taking action. In the early stages, US Ambassador Albright informed the Security Council that Washington was opposed to the reinforcement of UNAMIR under any circumstances, and that the US position was that all LN peacekeepers should be withdrawn (Neuffer 2002, 119). She also testified before the House Foreign Affairs Subcommittee, that it would have been 'folly' for America to venture too quickly into this African 'maelstrom' noting that: 'We want to be confident that when we do turn to the UN, the $\mathrm{LN}$ will be able to do the job' (Wheeler 2000, 228-9). No member of the House Commitree challenged this abandonment of humanitarian principles and so even the supposedly liberal Clinton administration was demonstrated to be in thrall to the concept of national interest, long after the supposed construction of a new world order founded on rule of law and adherence to global normative constraints.

French national interest extended to the maintenance of Francophone regimes in the face of perceived Anglophone expansion, regardless of their human rights records. Furthermore, extensive ties between the socio-economic, political and military elites in France and Rwanda added to the perceived obligation to Rwanda's rulers rather than Rwanda's people. When the crisis erupted, the French landed 190 paratroopers with a mission to evacuate foreign nationals but no Rwandans. Yet while 'the embassy's Rwandese personnel, who were mostly Tutsi, was cold-bloodedly abandoned to certain death' dignitaries of the Habyarimana regime including Mmc. Habyarimana, her children, her brother Seraphin Rwabukumba with his death-squad colleague Alphonse Ntirivamunda and a number of other Hutu extrcmists were saved (Prunicr 1995, 23/(-5).

Thus France's decision-makers were at this time clearly more heavily influenced by the duty owed to a friendly (to France at any rate) regime than the duty owed to common humanity. Rwanda's political, military and economic elites with whom Paris had cultivated ties over two decades were Francophone, but most of the members of the RPF were English-speaking, having grown up in Anglophone Uganda. The Arusha process was also considered to be 'Anglo-tainted' due to Tanzania's leading role, as was UNAMIR's logistic line to the Ugandan city of Entebbe. 'French policy since 1990 had been influenced by such considerations, and they were evident in 1994 when itance acting jointly with Senegal developed logistics in Francophone Zaire and equipped Francophone troops to replace the departing soldiers of "Operation Turquoise".' (Klinghoffer 1998, 87).

If Paris had truly been motivated by humanitarian concerns, its purposes would 
have been better served by helping to supply, fund and push for a stronger mandate for. UNAMIR II. That the French Government was as hesitant as any other in taking this route, had voted along with the rest of the Security Council to cut UNAMIR, and did nothing during the worst of the genocide to prevent the killings, though they probably had greater knowledge of what was happing than any other member of the international community, shows that its priorities lay elsewhere. (Butcher, 2004).

Thus Western efforts in the early days of the crisis focuscd on protecting their own nationals and those of other states with whom they doscly identified, i.e. other members of the Atlantic Community. One thousand five hundred Belgian, French and Italian troops wete dispatched within the first week following the planc crash to evacuate embassy staff, dependents, and other foreign nationals. 'So urgent did the LN deem the evacuation that it was the only tinc during the genocide that Dallaire was authorized "to act beyond (his) mandace" and provide assistance," and according to Neuffer, "the West could not have provided a clearer signal of its indifference to the genocide's plannets.' (2002, 117-8). For Prunier, 'the hurried evacuation was a disgrace.' Tutsis 'were taken off the vehicles at militia roadblocks and slaughtered under the eyes of the French or Belgian soldiers who, obcying their orders, did not react' $(1995,235)$.

According to the Report of the Independent Encuiry, the UN Force Commander 'found quite carly on that he did not have the practical command of all his troops: for all practical purposes the Belgian peacekeepers [the largest contingent] came under the command of their national evacuation troops' and 'UNAMIR was sidelined in relation to the national evacuation operations conducted by France, Belgium, the Linited States and Italy.' 'I'hus one of its recommendations was that 'troop contributing countries, despite domestic political pressures which may argue the reverse, should refrain from unilateral withdrawal to the detriment and cven risk of ongoing peacekeeping operations' (1999).

Only after international news reporters and TV crews had artived in great numbers on their way back from covering President Mandela's inauguration in South Africa, did the decision-making elites of leading Western states feel compelled to act. Wheeler notes that horrifying television images of mutilated bodies floating down blood-soaked rivers, growing evidence that a genocide was caking place, and pictures of a terrible human exodus as up to half a million fled across the Tanzanian border in search of safety, embarrassed the Permanent Members over their inaction. (2000, 225).

Additionally, representatives of smaller Member States responded to media coverage and NGO briefings by applying pressure behind the scenes and threatening to go public with their criticisms of UN Security Council inaction. 'Ihis led to an informal meeting of the Security Council on 28-29 April. 'The New Zealand Ambassador was the President of the Council for April, whereas the Czech Ambassador Karel Kovanda's family were survivors of the Holocaust, and he likened the UN's approach as "rather like wanting Hitler to reach a ceasefire with the Jews" (Wheeler 2000, 226). Eventually, by the end of June, "stung by shame; criticized for failing to react 
swiftly, both the IJN and the Linited States searched for a solution' (Neuffer 2002, 129).

\section{T'HE LEGACY}

International statesmen chose not to act while genocide was taking place in Rwanda because it did not serve their material interests or those of their citizens to do so. They finally chose to act over the refugec crisis because of guilt over previous inaction, and pressure from citizens and the international community that helped redefinc national interest in terms of reputation and compassion as well as direct material interests.

Wheeler demonstrates this process at work among French decision-makers. On 10 May, Mitterand stated that "the international community could not act as a global police force and send pacekeepers to all the places where people fight,' and this position was supported by Prime Minister Edouard Balladur and Defence Minister Francois Leotard, "who took the view that France could no longer assume the role of a hegemonic power in Africa.' Yet this position apparently becamc "increasingly untenable as abhorrent television pictures of the killings and lobbying by NGOs generated growing domestic pressure on the French government to act' $(2000,235)$.

It would seem from the above assessment that by 1994, not only was there still no sign of the brave new norm-ruled world in which international military interventions took place according to the dictates of humanitarian need, but aiso that the more limited legalistic vision inspired by the Gulf War was proving to be nothing more than a mirage. Material national self-interest appeared to dictate the rational decision-making of leaders. However, this would be a false impression, and ignores a few kcy, if somewhat subtle, elements of the Rwandan non-intervention.

Firstly the UN and Member States were ultimatcly compelled to take some form of action by pressure from international and domestic public opinion fuclled by information from NGOs and the media. Secondly, the French acknowledged that despite their eagerness to intervene they would have been prevented from so doing without the legitimation of Security Council endorsement. Furthermore, they did everything possible to increase the legitimacy of the intervention, from trying to include other mombers of the European Union, to eventually including token contingents from African metrubers of La Francophonie. Thirdly, what prevented other Members of the Security Council from admitting that a genocide was taking place was an awareness that if such were proven, then international law would compel them to intervene, regardless of costs and the dictates of individual national interest. Finally, the failure to act in this instance increased international normative pressurc for action in future cases of 'practices that shock the conscicnce of humankind.'

In fact, the Rwandan case is so complex because it marks a transitional stage in the evolution of post-Cold War international society. State-centric considerations 
of material national interest continue to weigh heavily upon decision-makers' calculations as to whether it is rational to embark upon a particular military escapade. It appears there would have to be some national interest involved in order to provoke participation, and the greater the national interest, the more likely is participation. However, the concept of national interest has been expanded to include considerations of the will of the people and reputation within the intemational community. Internal and external constituencies appeat to have been increasingly sensitised towards normative considerations through the efforts of non-governmental organizations, pressure groups, human rights activists, and the impact of ever more pervasive mass media and the justifications of international actors themselves.

The Rwandan crisis added two new considerations to the heritage of the post-Gulf War New World Order: an awareness that mass-media could be used not only by governments to manipulate perceptions of internal constiruencies to support military forays, but also could mobilise internal constituencies to put pressure on decision-makers to enter into campaigns, and that revulsion or compassion could exercise as much influence of the pubic as appeals to their rationality; and an awareness that guilt, or the shadow of history acts as a further set of criteria constraining decisions.

\section{NEW CASES}

Madeleine Albright, the Linited States Ambassador to the UN during the Rwandan crisis and Secretary of State during the Kosovo campaign, is perhaps the best example of the transformation wrought upon the racional calculations of key decision-makers as a result of inaction guilt. As noced above, she was instrumental in putting ever more barriers in the way of American intervencion in Rwanda. However, post-Rwanda she became such a fietce advocate of the humanitarian use of military interventionary force, that Kosovo has been termed by many 'Madclcinc's War.' In an interview at Fwha Graduate School of International Studies, Scoul, Korea, on 12 November 2002, when questioned Albright confirmed that the previous cases where the Unired States and the international community had 'waited too long to go in' had 'played a huge role' in determining policy over Kosovo. (Albright 2002).

Likewise Presidcnt Clinton expressed this guilt during a visic to Rwanda in March, 1998 and acknowledged the impact it would have upon future decision-making. He first admitted that a genocide had taken place, that the killings were neither spontaneous, accidental, not the result of ancient tribal struggles, and that people everywhere had the capacity to slip into pure evil. Furthermore, he stated that 'we cannot abolish that capacity, but we must never accept it. And we know it can be overcome.' He conceded that the world had not acted quickly enough and accepted the collcctive guilt, stating 'the international community, together with nations in Africa, must hear its share of responsibility for this tragedy, as well. We did not act quickly enough after the killing began. We should not have allowed the refugee 
camps to become a safe haven for the killers. We did not immediately call these crimes by their rightful name: genocide' (Clinton 1998) Clinton went on to acknowledge how this guilt would impinge upon future deliberations. He noted that although we cannot change the past, we can and must do everything in our power to help build a future without fear, and full of hope.

Wc owc to those who died and to those who survived who loved them, our every effort to increase our vigilance and strengthen our stand against those who would commit such atrocities in the future - here or elsewhere. Indeed, we owe to all the peoples of the world who are at risk - because each bloodletting hastens the next is the value of human life is degraded and violence becomes colerated, the unimaginable becomes more conceivable - we owe to all the people in the world our best efforts to organize ourselves so that we can maximize the chances of preventing these events. And where they cannot be prevented, we can move quickly to minimize the hurror (Clinton 1998).

Clinton further revealed that he was instructing his administration to improve its systems for spotlighting countries in danger of genocidal violence, and outlined the necessity for the international community to have the ability to act when genocide threatens (BBC 1998). A combination of guilt over inaction in Rwanda and similat inaction in Bosnia meant that the Clinton administration was not going to sit idly by when a case that seemed to contain elements of both thuse tragedies next appeared. Kosovo was to be the first explicitly humanitarian intervention in the post-Cold War world. The cagerness to get involved in Kosovo contrasts most vividly with reluctance over Rwanda, as docs the relative absence of consikerations of material national interest compared with the Gulf. At the time much was made in the press and in public debate of the idea that liberal politicians were the new hawks, whereas conscrvative or realist commentators were comparatively non-interventionist.

In Clinton's first public statement on the issue, prior to discussions with the United Nations Secretary-Genetal Kofi Annan, in March 1998, human rights featured most strongly, rather than security or other considerations of national interest that might have been emphasized at other times in other circumstances. "We do not want the Balkans to have more pictures like we've scen in the last few days, so reminiscent of what Bosnia endured. And I want to make it very clear that to me it's a very scrious issue... We believe that no option should be ruled in or out now' (Public Papers I 1998, 355-366).

Here it is interesting to note that not only does Clinton emphasize the human rights implications of what was happening, but also the impace of media pictures, the lessons of failing to intervene in previous cases of human rights abuse, and the fact that a military intervention to counter human rights abuses would not be ruled out. The emphasis on human rights and the attempts at coalition building continued 
in the public statements leading up to the intervention and during the conflict itself. In a joint statement on the situation in Kosovo with the Russian President in September 1998, Clinton deplored the heavy suffering inflicted on innocent civilians, and announced that the 'threat of humanitarian catastrophe is becoming ever more real (Public Papers II 1998, 1501.' In October Clinton told reporters: 'I think the most important thing now is for us to save lives, retum people to their homes, get them the humanitarian aid they need, and to remove completely and irrevocably the threat of aggression by the Serb military and other forces in Kosovo now (Public Papers II 1998, 1794).'

In his radio address of liebruary 13, 1999 Clinton explicitly linked American national interest with the protection of human rights and made a casc for a proportional intervention in anticipation of further suffering if action werc not taken. (Public Papers I 1999, 190). And in March he hailed the success of threat of force in preventing further human rights abuses (Public Papers I 1999, 317). Clearly, however, this claim of success proved premarure and later in the same month, in preparation for military action, he again reminded the public of the horrors been perpetrated by the Serbian regime:

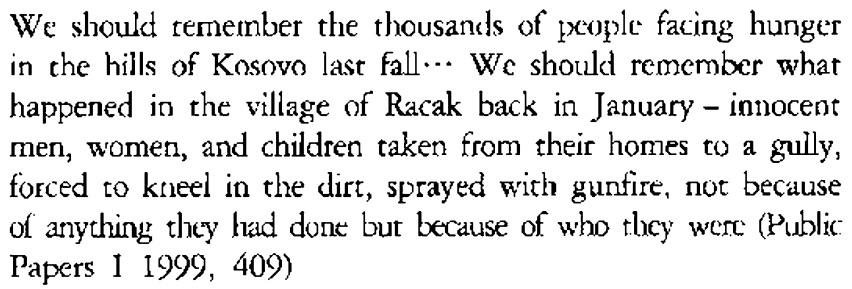

Indeed it is very hard to make a national interest case for the intervention in Kosovo. As pointed out by the Amnesty International Report, although naturally rich in resources, including large deposits of lead, zinc, nickel and magnesium, Kosowo province is economically one of the poorest regions in the Balkans. It is the most heavily populated region in the Fedcral Republic of Yugoslavia and suffers from high unemployment $(1998,29)$. On the other hand, the cost of the war and the clamage it caused could, according to third party estimates, be as high as $\$ 100$ billion. This is equal to over $\$ 50,000$ for every man, woman and child in Kosovo (Littman 1999; vii). Thus by the end of the action, the prize was certainly not going to be worth having in terms of macerial gain, especially when, according to International Institute for Strategic Studies estimates, the utilisation and replacement cost of NATO's campaign amounted to $\$ 11$ billion with the peace-keeping and support for Kosovo estimated (by the United Nations) at a further $\$ 7.7$ billion per annum (Littman 1999, vii).

Not surprisingly therefore tealists such as Henry Kissinger and Colin Gray repeatedly and convincingly argued against the intervention saying that no vital US military or political interests were at stake, and that 'moral outrage is not a sound base for policy,' but nevertheless conceded that 'periudically it is so insistent that prudent policy-makers must bow to its demands. (Owens 5)' 
Kosovo demonstrated that even international law was not going to stand in the way of normative war fighting, as it was not an action of individual or collective self-defence, had not been sanctioned by the UN' Security Council, and, however distasteful we might have found the actions of the Belgrade regime, Serbian forces were not technically waging a war of aggression despite allied attempts to portray it as such. Allied claims regarding the dangers of escalation were clearly an exaggeration of the threat posed to international security by the situation in Kosovo, besides which, Article 39 of the UN Charter clearly states that it is up to the Sccurity Council to decide upon such definitions.

However, this is not to suggest that as a result of Rwanda, the leaders of the Atlantic Community would authorise any and all humanitarian missions put before them. Rwanda demonstrated the ongoing relevance of material considerations combined with an awareness of how normative considerations could form part of the operating environment within which rational decisions were made. A geopolitical motive rather than a humanitarian one can even be attributed to Albright's apparent conversion at some time between Rwanda and Kosovo. Albright closely identified with East-Central Europe in a way that she did not with Africa. Twice during her childhood her family was forced to flec Czechoslovakia, once in 1939 following Hitler's annexation of the country and again in 1948 after the Communist government stripped her father, who had been the Czexh ambassador in Belgracle, of his citizenship. Thus her enthusiasm for countering totalitarian regimes in the region may have had far from global normative roots.

Fergal Keanc, a reporter who has also written an insightful book on the Rwandan genocide, recorded an intervicw with his translator in Rwanda at the time of the Kosovan intervention. Asked what the Rwandans thought about Kosovo 'Michael' replied: "We are amused by you white people. So much concern when it is on your own doorstep. Is it because they have white skins that there is so much attention being paid?' (Keane 1999). This was a common perception in Rwanda as detailed by the Report of the Independent Enquiry: "It has becn stated repeatedly during the course of interviews conducted by the Inquiry that the fact that Rwanda was not of strategic interest to third countries and that the international community exercised double standards when faced with the risk of a catastrophe there compared to action taken elsewhete' (1999). Thus the most recent, and at the time of writing (August/September 2004), ongoing case, that of Sudan, may prove a better indicator of the lasting influence of the Rwandan failure.

In early 2003 African tribal peoples of the Darfur region rose in rebellion against marginalization imposed on them by the Khartoum regime. The Government response was reported to be brutal, and in a worrying echo of Rwanda, pro-Govemment militias scemed to be taking the lead in striking against the rebels, and were showing no morcy. As early as July 2003 Amnesty International was warning of a 'looming crisis in Dasfur' (Amnesty 2003), and by February of 2004 was talking of an 'invisilule, vicious conflict' in which the majority of casualties are civilian. 'The extent of the 
destruction of lives and livelihoods in Darfur since the conflict started is alarming: within a few months, hundreds, if not thousands of civilians have been killed in deliberate or indiscriminace attacks. Hundreds of thousands have been displaced by the attacks (Amnesty 2004, 1).' The speed and extent of the destruction also draws parallels with Rwarda.

Again the international community is aware of what is happening. On 9 December 2003 Kofi Annan stated that he" was "alarmed at the rapidly deterioraring humanitarian situation in the Darfur region of the Sudan, and by reports of widespread abuses against civiliuns, including killings, rape and the burning and looting of entire villages" (Amnesty 2004, 1) and in April 2004, a UN team investigating human rights abuses in the region found "disturbing patterns of massive human rights violations in Darfur, many of which may constitute war crimes andior crimes against humanity" (In These Times 2004, 1).

However, this time the leadership of the international community is taking a much more active role. UN Secretary General Kofi Annan, US Secretary of State Colin Powell and UK Foreign Secretary Jack Straw were dispatched with alacrity to Sudan precisely to prevent a repetition of the criticisms leveled at the international community's inaction in Kwanda. liven though human tights groups such as Amnesty International and Human Rights Watch have condemned the atrocities and urged the international community to take action, they have shicd away from calling the human rights abuses "genocide," instead referring to them as "echnic cleansing." Yet as early as July 22, 2004 the American Congress passed a resolution unanimously in both the House and Senate declaring the unfolding atrocities genocide. On September 9 Powell told a meeting of the Senate foreign relations committee: "I concluded that genocide has been committed in Darfur and that the government of Sudan and the Janjaweed bear responsibility and that genucide may still be occurring" (La Guardia 10 Sept 2004). Finally, on 16 September the European Parliament joined in the accusations of genocide (Telcyraph 1994).

The samc states and organizations who failed Rwanda have also been active in pledging more than words co counter a similar catastrophe in Sudan. Sir Mike Jackson, Chief of the General Staff of the British Army told the BBC in late July that a brigade of 5,000 soldiers could be ready and fully equipped if the government decided to send troops in CNN.com 2004). On July 30 Security Council Resolution 1556 (sponsored by, among others, the US, UK and France) 'demanded that the Government of the Sudan disarm the Janjaweed militias, apprehend and bring to justice its leaders and their assuciates who had incited and carried out violations of human rights and international humanitarian law, as well as other atrocitics in the country's Darfur region' (Security, Council 2004). This resolution gave Khartoum 30 days to show progress on the commitments outlined in a joint communique signed by the UN and the Sudanesc Govctument (Joint Communiqué 200/), or else face action undet Article 41 of the UN Charter including unspecified economic and political sanctions.

In August the African Union agreed to send more than 300 Nigerian and Rwandan 
troons to support the $100+$ ceasefire monitors in the region. On September 7 French soldiers based in Chad established a supply airlift for Darfur refugees (Agence France-Presse 2004). By this date the World Food Programme's emergency operation in Darfur had received US\$158 million, including US\$74 million from the US, US\$22.8 million from the European Commission, US\$3.9 million from Australia (who had also offered to send troops), US\$3.08 million from the UK, US\$1.24 million from France, and LS\$1.22 million from Belgium (WFP 2004).

The UN deadline has recently expired, and Khartoum has failed to comply with all that was required of the regime by the international community. Indeed, the killings go on, and the regime is even reported to have been hampering the mission of the AL; troops already on the ground (Joffe-Walt 2004). Jan Pronk, Special Representative of the Secretary-General acknowledged that the Sudantse Government had made some progress towards meeting the requirements of Resolution 1556, but not enough (UN Security Council 2004). However, he also said that it was not yet the time to use sanctions (Agence France-Presse 6 Sept, 2004). Yet despite the Sudanese Government calling upon the international community to give it more time to deal with the crisis (Deutsche Presse Agentur 2004), there are signs of growing impaticnce with the impasse.

On 6 September Nigerian President Olusegun Obasanjo intervened personally to prevent the collapse of peace talks (Reliefweb 2004, a), on 7 Septembxr Annan called for international support to expand the AUJ force from its original "woxfully inadequate" number (Reliefwets 2004, b), and both the US and UK have been srepping up the pressure and threats and drawing analogies with Rwanda. Jack Straw told the LK Parliament "the situation is one which has rightly shocked the world. For our part, we are determined to do everything we can to resolve the humanitarian disaster and help secure a political settlement across the country as a whole. Ten years ago, the world turned away from the horrors of Rwanda and Bosnia. We all know the appalling result" (Kecpmedia 1994). Meanwhilc on September 8 the US threatened to impose sanctions on Sudan's crucial oil industry Ja Guardia 9 Sept 2004). Nigeria and other members of the AU, Annan and the UN, the US and the UK had all come in for severe criticism for inaction in Rwanda, and it seems that they are keen to demonstrate that they have learned the lesson. At this time it is too early to tell whether the international community will take adequate action, but at least they seem united in declaring what is happening a genocide and accepting that something must be done this time.

\section{CONCLUSION}

Liberal assumptions concerning a brave new post-Culd War world were proven by Rwanda to be premature. This article demonstrates that deciston-makers of the international community, including those representing supposedly liberal states, were 
still primarily motivated by narrow self or national interest rather than concern for the promotion and protection of human rights which otherwise would have compelled them to take action. Likewise, although awarencss of the duties imposed under international law was enough to structure excuses for inaction, it was not enough to motivate states to intervene, so there was still insufficient evidence of "the rule of law" proclaimed by President Bush three years previously.

However the Rwandan genocide proved to be a crisis in terms of all the concepts associated with the word. It represented threat, opportunity and a turning-point in the theory and practice of humanitarian intervention. This article further (uniqucly) shows the impact of the scars of Rwanda upon decision-makers when faced with future cases of humanitarian catastrophe. As a result of Rwanda human rights have become part of the national interest of the dominant states in the international community to an extent that such considerations have become largely internalized and in many cases are taken as read - a very different state of affairs from that prevalent during the Cold War. The crisis highlighted the role played a more pervasive, globalized, instantaneous media, and by an increasingly informed and articulate public opinion that can no longer be ignored by decision-makers standing for election on a regulat basis. We may nut yet have a brave new liberal world (the jury is still out on that one, and sentence may only be passed after conclusion of the Darfur crisis), but we certainly have sumcthing very different from the old power-political world described by realists.

\section{REFERENCES}

Agence France-Presse. 2004. Not Yet Time for Sanctions against Sudan: LN Envoy, September 6.

Agence France-Presse. 2004. French Begin Airlift to Darfur Refugees in Chad, September 7 .

Albright, Madcleinc 2002. Interview at Ewha Graduate School of International Studies, Senul, Korea, November 12.

Amnesty International. 1998. Kosovo: the Evidence. London.

Amnesty International. 2003. Sudan: Looming Crisis in Darfur. London, July 1.

Amnesty International. 2004. Darfur: Too Many People Killed for No Reason. London, February 3.

BBC News Special Report. 1998. Clinton Speaks Out on Rwandan Genocide, http:/news.bbc.co.uk/L/hi/special_report/1998/03/98/africa/69581.stm (March 25).

Butcher, Tim. 2004. France Accused of Genocide by Rwanda's Leader. The Daily Telegraph, March 22.

Cinn.com. 2004. Sudan Says Conflict "Not Genocide," July 24.

Des Forges, Alison. 1999. Leave None to Tell the Story: Genocide in Ruanda. New York: Human Rights Watch. 
Destexhe, Alain. 1995. Ruanda and Genocide in the Twentieth Centum. Iondon: Pluto Press.

Deutsche Presse Agentur, 2004. Sudan Calls for "More Time" to Solve Darfur Crisis, September 7 .

Fukuyama, Francis. 1989. The End of History? The National Interest 16.

Fukuyama, Francis. 1992. The End of History and the Last Man. New York: The Free Press.

Gourevitch, Philip. 2000. We Wish to Inform You that Tomorrow We Will Be Killed with Our Families: Stories from Ruanda. London: Picador.

Howc, Brendan. 2004. Comparative Military Interventions: The Question of Legitimacy, Ph.D. thesis, University of Dublin.

In These Times. 2004. Genocide in Sudan, http://www.inthesetimes.com/sitc/main/print/ genocide in sudan/ (May 6).

Joffe-Walt, Benjamin. 2004. Sudan Hinders African Mission to Protect Darfur, The Sunday lelegraph, September 5.

Keane, Fergal. 1996. Season of Blood: A Ruandan Joumey. London: Penguin.

Keane, Fergal. 1999. Rwanda and Kosovo: the same beneath the Skir. The Sunday Telegraph, April 11.

Kecpmedia, 2004. Britain Wants UN to Sct Khartoum Clear Targets over Darfur, September 7.

Klinghoffer, Archur Jay. 1998. The Intomational Dimension of Genocide in Rwande. New York: New York University Press.

Kuperman, Alan J. 2000. Rwanda in Retrospect. Foreign Affair 79 (1): 94-118. La Guardia, Anton. 2004. US Raises Threat of Oil Embargo on Sudan, The Daily Telegraph, September 9.

La Guardia, Anton. 2004. Darfur Killings "are Genocide", The Daily Telegrapb, September 10.

Melvern, Linda. 2000. A People Betrayed: The Role of the West in Rwanda's Genocide. lundon: Zed Books.

Littman QC, Mark. 1999. Kojrois: Law E Difhlomuy Iondon: Centre for Policy Studics.

Neuffer, Elizabeth. 2002. The Key to My Neigbbrur's House: Seeking Justice in Bosnia and Ruanda. London: Bloomsbury.

National Archives and Records Administration, Office of the Federal Reyister. 1999. Public Papers of the Presidents: William J. Clinton 1998 Book I: January 1-June 30, 1998.

National Archives and Records Administration, Office of the Federal Register. 2000. Public Papers of the Presidents: William J. Clinton 1998 Book ll: July 1-December 31, 1998.

National Archives and Records Administration, Office of the Federal Register. 2000. Public Papers of the Presidents: William J. Clinton 1999 Book I: January 1-Junc 30, 1.999.

Owens, Patricia. IR Theory in Practice: Case Studies. Oxford L'niversity Press, web 
support material Section 1: 5, http://www.oup.co.uk/best.textbooks/politics/globalization 2e/theory-practice.

President Clintm Apnlogizes. Text of President Clinton's Address to Genocide Survivors at the Airport in Kigali, Rwanda, on March 25, 1998, as Provided by the White House and Reported by The Associated Press, March 25, 1998, http:/www. sweetsassyass.com/holoRwanda.heml.

Prunier, Gerard. 1995. 17e Rwanda Crisis; History of a Genocide. London: Hurst \& Co.

ReliefWeb. 2004. Annan Calls for International Support to Expand African Force in Darfur, Sudan.

ReliefWeb. 2004. Joint Communicpuc betwren the Govetnment of Sudan and the United Nations on the Occasion of the Visit of LJN SG to Sudan, 29 Jun-3 Jul 2004.

ReliefWeb. 2004. Nigeria-Sudan: Obasanjo Called in to Prevent Collapse of Darfur Peace 'Talks.

Ross, Philip. 2002. A Non-Liberal Approach to the Concept of an International Order. In Human Rights and Military Intervention, ed. Alexander Musely and Richard Norman. Aldershot: Ashgate.

The Daily Telegraph. 1998. UN Genocide Alert widely Circulated, April 13.

The Daily Telegraph. 2004. Euro-MPs Accuse Sudan of Genocide, September 17.

United Nations(UN). 1996. The United Nations and Rwanda 1993-1996. New York: United Nations.

United Nations Fconomic and Social Council. 1999. Report of the Independent Inquiry into the Actions of the United Nations during the 1994 Genocide in Rwanda. December 15.

Linited Nations Secuirty Council. 2004. Resolution 1556(2004). Adopted by the Secuirty Council at its 5015th Mceting, July 30.

Linited Nations Secuirty Council. 2004. Sudan Has not Disarmed Militias or Stopped Attacks on Civilians in Darfur, Special Representative Tells Security Council. September 2.

Vassall-Adams, Guy. 1994. Rwanda: An Agenda for International Action. Oxford: Oxfam. Whecler, Nicholas J. 2000. Saving Strangers. Oxford: Oxford University Press. World Food Programme. 2004. Long and Difficult Road ahead in Darfur as WFP Feeds one Million, September 7. 